\title{
Influence of Variations in Wastewater on \\ Simultaneous Nutrient Removal in a Pre-anoxic Selector Attached Full-scale Sewage Treating SBR
}

Ghazal Srivastava ( $\square$ ghazalsrivastava1247@gmail.com )

IIT Roorkee https://orcid.org/0000-0002-5005-1944

\section{Ankur Rajpal}

Indian Institute of Technology Roorkee

\section{Anwar Khursheed}

Aligarh Muslim University

\section{Ashok Kumar Nadda}

Jaypee University of Information Technology Department of Biotechnology and Bioinformatics

Vinay Kumar Tyagi

Indian Institute of Technology Roorkee

Absar Ahmad Kazmi

Indian Institute of Technology Roorkee

\section{Research Article}

Keywords: Oxidation-Reduction Potential, Sequencing Batch Reactor, Simultaneous Nitrification and Denitrification, Soluble Chemical Oxygen Demand, Total Chemical Oxygen Demand

Posted Date: February 11th, 2021

DOl: https://doi.org/10.21203/rs.3.rs-214129/v1

License: (c) (i) This work is licensed under a Creative Commons Attribution 4.0 International License. Read Full License 


\section{Abstract}

In addition to many other well-documented factors, local conditions are rudimentary conditions of sharp change observed in wastewater characteristics from place to place. An optimized and flexible treatment strategy is required to handle these fluctuations and variations in quality. Pre-anoxic selector-equipped sequencing batch reactors (SBR) perform efficiently in removing COD, $\mathrm{BOD}_{5}, \mathrm{TSS}, \mathrm{NH}_{4}{ }^{+}-\mathrm{N}, \mathrm{TN}$, and Fecal Coliforms. The monitoring of 3-MLD Full-scale SBR installed at IIT, Roorkee, drew attention to the processes involving simultaneous nitrification and denitrification (SND) and biological phosphorous removal (BPR) undergoing with the variations in influent wastewater, particularly the readily biodegradable COD ( $\mathrm{rbCOD}$ ), and their effects on micro-biota. Regular monitoring of all the units for a period of six months revealed that the overall average treatment/ removal efficiencies were $>94 \%$ COD (17.9 $\pm 7.7 \mathrm{mg} / \mathrm{L}$ in effluent), $>95 \% \mathrm{BOD}_{5}(5.9 \pm 2.2 \mathrm{mg} / \mathrm{L}$ in effluent), $>95 \% \mathrm{TSS}(9.3 \pm 2.1 \mathrm{mg} / \mathrm{L}$ in effluent), $>96 \% \mathrm{NH}_{4}-\mathrm{N}(0.7 \pm 0.5 \mathrm{mg} / \mathrm{L}$ in effluent), $>86 \%$ TKN $(4.2 \pm 2.9 \mathrm{mg} / \mathrm{L}$ in effluent), $>69 \% \mathrm{TN}(9.7 \pm 3.0 \mathrm{mg} / \mathrm{L}$ in effluent $),>31 \%$ Ortho- $-\mathrm{PO}_{4}-\mathrm{P}(1.8 \pm 0.7 \mathrm{mg} / \mathrm{L}$ in effluent $)$ and $>42 \% \mathrm{TP}(3.6 \pm 1.8 \mathrm{mg} / \mathrm{L}$ in effluent $)$ and achieved $<50 \mathrm{MPN} / 100 \mathrm{~mL}$ fecal coliform in the final effluent after disinfection. Anoxic tri-sectional selector and an aeration tank constituted one SBR followed by the other availed $76 \pm 9 \%$ SND at $\mathrm{rbCOD} / \mathrm{TCOD}$ of $0.12 \pm 0.04$, rbCOD/sCOD of $0.33 \pm 0.10$, sCOD/TCOD of $0.35 \pm 0.06$, and COD/TN of $\sim 13$. The study clarifies the degree of variations in key factors included in design guidelines for laying out an optimized treatment system for COD, Nitrogen, and Phosphorus removal in the Indian scenario.

\section{Highlights}

- Evaluation of Pre-anoxic selector-equipped full-scale SBR based STP was performed.

- $>90 \%$ removal of COD, $\mathrm{BOD}_{5}$, Ammonia, and TSS was observed.

- Bio-selector improved the sludge morphology and enhanced the SND and BPR processes.

- The rbCOD concentration significantly affects the denitrification and TP removal.

\section{Introduction}

A comprehensive data of total organic matter present in the wastewater can be achieved by characterizing total COD (TCOD) into its various fractions. Additionally, the major characteristics of wastewater can be studied based on COD fractionations following ATV-A.131, 2000 guidelines, and subsequent modifications (Płuciennik-Koropczuk and Myszograj 2019). The TCOD of wastewater, segregated in fractions, can be calculated as the sum of readily biodegradable COD (rbCOD) (metabolism), non-biodegradable soluble COD (nbsCOD) (observed in the treated effluent), biodegradable particulate COD (bpCOD) (i.e., slowly biodegradable COD (sbCOD)) (adsorption, hydrolysis, and metabolism) and non-biodegradable particulate COD (nbpCOD) (regarded in the sludge production) as $\mathrm{g}$ $\mathrm{O}_{2} \mathrm{~m}^{-3}$ (Choi et al. 2017; Płuciennik-Koropczuk and Myszograj 2019). The general rbCOD/ TCOD in South African wastewater's raw sewage: 0.08 to 0.25 (Rossle and Pretorius 2001). The substantial the amount of rbCOD, the faster the nitrate reduction rate (Metcalf and Eddy, Inc. 2003). It has been investigated in 
different studies that carbon to nitrogen ratio $(\mathrm{C} / \mathrm{N})$ is an essential factor in biologically removing the nutrients ( $\mathrm{N}$ and $\mathrm{P}$ ) from domestic wastewaters, however readily biodegradable content in the TCOD also in particular directs the nutrient removal efficiency (Khursheed et al. 2018). Denitrifying bacteria requires an optimum carbon source for succeeding in excellent denitrification, and therefore they have to contend with further heterotrophs. Lesser $\mathrm{C} / \mathrm{N}$ ratio in the influent effects in a rapid carbon discrepancy and consequences in unstable simultaneous nitrification and denitrification (SND) (Zhao et al. 2008;

Phanwilai et al. 2020).

Enhanced biological phosphorus removal (EBPR) governs the prominent characteristic of uptake of organic matter and release of phosphorus in anaerobic states, and uptake of excess phosphorus under subsequent aerobic conditions. High phosphorus is accumulated in the sludge by phosphate accumulating organisms (PAOs). Polyphosphates are reduced to supply adenosine triphosphate (ATP) obligatory for the formation of Poly- $\beta$-hydroxybutyrate (PHB), and the degradation of polyphosphates is achieved by the discharge of ortho $\mathrm{PO}_{4}-\mathrm{P}, \mathrm{Mg}$, Ca and K. (Toerien et al. 1990; Davis 2013). The rbCOD concentration in the influent predicts more accurately the performance of biological nutrient removal, consists of complex soluble COD that can be fermented to volatile fatty acids (VFA); therefore initial rbCOD to TP ratio is a better indication of the EBPR's process and performance than the total COD to $P$ ratio (Barnard et al. 2017). Hence, influent parameters like C/N, BOD ${ }_{5} / \mathrm{COD}$, rbCOD/ TCOD (/or rbCOD/ SCOD), and rbCOD/TP play an essential role in enhancing the SND and BPR as observed in the study.

Barely limited literature is available based on investigating the influence of wastewater characteristics on the nutrient removal process's efficiency in SBRs, so novel findings in the present study may prove useful for further researches in this field. Even the effect of an anoxic selector on the SND and EBPR process in SBR has not been explored to date. Moreover, the present study investigates the importance of anoxic bioselectors in improving sludge properties. As the main features concerning the activated sludge microbial diversity are the possible substrate composition of the incoming sewage and the ongoing significant operational variations in the treatment plant (Mielczarek 2012), therefore, this study aims to understand the pre-anoxic selector's effect and observe the influence of wastewater characteristics on Nitrification, Denitrification, and Biological Phosphorus removal in SBR. Concomitantly, the sludge biomass and wastewater microbiome were considered as critically important.

\section{Materials And Methods}

This 3-MLD SBR has been set up in close vicinity to the residential area near the IIT, Roorkee campus, Uttarakhand (India). The important features of this institutional STP are the deodorization system's additional odor control for sump well, pre-treatment units, and advanced tertiary treatment facility (Fibre Disc filtration and UV disinfection) (Figure 1). The onsite monitoring of various parameters was performed in the bio-selectors and aeration tanks of the 3 MLD SBR Plant.

\subsection{Physicochemical parameters' analysis}


Onsite monitoring of dissolved oxygen (DO), $\mathrm{pH}$, oxidation-reduction potential (ORP), and $\mathrm{SV}_{30}$ are executed regularly in the bio-selectors and aeration tanks of the 3 MLD SBR Plant. To determine the DO, temperature, and $\mathrm{pH}$ in the aeration tanks and selectors, a portable DO meter (Hach 110Q multimeter, Hach, USA) and pH meter (HQ11d pH Meter, Hach) was used. ORP was measured by the convenient ORP meter (HQ11d ORP Meter, Hach). Complete performance evaluation of the plants in terms of COD (total COD (TCOD) and soluble COD (SCOD)), Ultimate BOD (UBOD), BOD 5 (soluble and suspended), TSS, VSS, $\mathrm{NH}_{4}-\mathrm{N}, \mathrm{NO}_{3}-\mathrm{N}, \mathrm{TN}, \mathrm{PO}_{4}-\mathrm{P}, \mathrm{TP}$, Total Coliforms, Fecal Coliforms, and Sludge operational parameters were performed according to Standard Methods (APHA 2005). rbCOD was calculated using the modified flocculation filtration method prescribed by Wentzel et al. 2000. SV30 was measured using the measuring cylinder and timer. Grab samples of $0.5 \mathrm{~L}$ were used for analyzing the parameters mentioned above, according to Standard Methods (APHA 2005).

\subsection{Wastewater characteristics}

The design quality of raw sewage for the SBR plant is shown in Table 1. The experimental monitoring analysis revealed that the actual parameters in the wastewater were observed as $\mathrm{BOD}_{5}: 163.1 \pm 56.9$ $\mathrm{mg} / \mathrm{L}$, total COD: $400.9 \pm 129.3 \mathrm{mg} / \mathrm{L}, \mathrm{TSS}: 236.8 \pm 79.2 \mathrm{mg} / \mathrm{L}, \mathrm{TN}: 33.6 \pm 9.0 \mathrm{mg} / \mathrm{L}, \mathrm{TKN}: 32.8 \pm 8.9$ $\mathrm{mg} / \mathrm{L}$, and TP: $6.1 \pm 2.4 \mathrm{mg} / \mathrm{L}$. The ratio between VSS to TSS was found around $0.53 \pm 0.05$. The overall SRT of the plant was approximately 15 days. The designed flow rate and hydraulic retention times (HRT) were 3.2 MLD and 18.11 hours. The raw wastewater $\mathrm{pH}$ was $7.2 \pm 0.3$, and finally, treated effluent after disinfection was $7.4 \pm 0.2$ (Table S1, Supplementary Material). Table S2 (Supplementary Material) demonstrates the SBR phases of full-scale 3 MLD STP. Regular sampling and analysis were conducted for approximately 6 months in this plant.

Table 1: General designed and actual wastewater characteristics in 3 MLD full-scale SBR plant.

\begin{tabular}{|lll|}
\hline Parameters & Designed quality & Actual quality \\
\hline pH & $5.5-9.0$ & $6.85-7.55$ \\
\hline Total COD (mg/L) & 450 & $272-530$ \\
\hline BOD $_{5}(\mathrm{mg} / \mathrm{L})$ & 200 & $106-220$ \\
\hline TSS (mg/L) & 407 & $158-316$ \\
\hline TKN (as N) (mg/L) & 34 & $24-42$ \\
\hline TP (as P) (mg/L) & 7 & $3.7-8.5$ \\
\hline
\end{tabular}


The daily flow variation in the plant is represented in figure S1 (Supplementary Material). The daily flow rate was $1877 \pm 573 \mathrm{~m}^{3} / \mathrm{d}$. The flow rate was observed maximum in September (average $2426 \mathrm{~m}^{3} / \mathrm{d}$ ) since the wastewater was started feeding into the plant, i.e., June 2019.

\subsection{Total Nitrogen balance}

Mass balance calculations to be carried out mathematically for Nitrogen balance in the plant. The following equation is being used:

Mass of Influent TN = Mass of Effluent TN + Mass of TN denitrified + Mass of TN wasted with sludge (Eq. 1)

Where,

Total Nitrogen $=$ Ammoniacal- $\mathrm{N}+$ Nitrites + Nitrates + Organic- $\mathrm{N}$

The mass of total nitrogen in the dissipated sludge $(\mathrm{Kg} / \mathrm{d})$ was computed by the product of daily sludge wasted in L/d (q wasted), MLSS of the wasted sludge, and a fraction (\%) of total nitrogen contained in the sludge wasted. The fraction was around $1.6 \%$ to $2.7 \%$ in the sludge.

To estimate the denitrified part of TN, an indirect way was applied through deducting Mass of TN in wasted sludge and Mass of TN in the effluent from the Mass of TN in the influent wastewater. The incoming wastewater's flow rate ' $Q$ ' is $1.87 \pm 0.6 \mathrm{MLD}$, while ' $\mathrm{q}$ waste' is a wastage flow rate of approximately $5.84 * 10^{3} \mathrm{~L} / \mathrm{d}$ with six cycles per day in the $2 \mathrm{SBR}$ tanks. All the masses are taken as $\mathrm{Kg} / \mathrm{d}$, and mixed liquor suspended solids (MLSS) concentration in $\mathrm{g} / \mathrm{L}$.

\subsection{Microscopic analysis for identification of protozoa and PHBs}

Microscopic analysis for protozoa, metazoan, filamentous and foaming organisms, bacteria, sludge floc morphology was observed at 10,20,40, and 100X magnifications. Qualitative microscopic observations were carried out in a mixed liquor sample of the aeration tank. Aliquots of $25 \mu \mathrm{L}$ sludge were examined under phase contrast (Radison RXLr5) illumination at $40 \mathrm{X}$ and 100X magnifications. PHBs identification is being carried out using Sudan Black B dye staining at 100X magnification (with immersion oil) by using a Light phase-contrast microscope (Optika microscope) (USEPA 1987; Sharma and Dhingra 2015; Ong et al. 2014). Microscopic observations were obtained for protozoa and PHBs after staining the samples.

\section{Results And Discussion}

\subsection{Observation-based on the influence of wastewater and quantitative analysis}

After the basic wastewater characteristics and analysis, thorough wastewater characterization was performed to estimate the various portions (fractions) of total COD in the 3 MLD SBR plant (Figure 2). 
Table S3 (Supplementary Material) shows the methodology used to determine different COD fractions in the plant. Wastewater characterization of 3MLD SBR, IITR, resembles the sewage characteristics reported by Rossle and Pretorius (2001). Table 2 gives us an estimated range of different COD fractions in reported studies.

Table 2: COD fractions in municipal raw wastewater

\begin{tabular}{|c|c|c|c|c|c|}
\hline $\begin{array}{l}\text { Location of incoming } \\
\text { wastewater }\end{array}$ & $\begin{array}{l}\text { rbCOD } \\
\text { (Ss) } \\
\%\end{array}$ & $\begin{array}{l}\text { nbsCOD } \\
\text { (Si) } \\
\%\end{array}$ & $\begin{array}{l}\text { bpCOD } \\
\text { (sbCOD) } \\
(\mathrm{Xs}) \\
\%\end{array}$ & $\begin{array}{l}\operatorname{nbpCOD}_{(\mathrm{Xi})} \\
\%\end{array}$ & Reference \\
\hline Flawil, Switzerland & $10-20$ & $7-11$ & $53-60$ & $7-15$ & Kappeler, Gujer, 1992 \\
\hline Istanbul, Turkey & 9 & 4 & 77 & 10 & Sozen, 1998 \\
\hline Zielona Góra, Poland & $\begin{array}{l}50.0- \\
61.7\end{array}$ & $2.2-6.0$ & $22.0-34.4$ & $8.0-16.2$ & $\begin{array}{l}\text { Płuciennik- } \\
\text { Koropczuk, } \\
\text { Myszograj, } 2017\end{array}$ \\
\hline South Africa & $20-25$ & $8-10$ & $60-65$ & $5-7$ & Ekama, 1986 \\
\hline Kielce, Poland & $24-32$ & $8-11$ & $43-49$ & $11-20$ & Henze, 2002 \\
\hline South Africa & $8-25$ & $4-10$ & $50-77$ & $7-20$ & $\begin{array}{l}\text { Rossle and } \\
\text { Pretorius, } 2001\end{array}$ \\
\hline $\begin{array}{l}\text { India (3 MLD SBR STP, IIT } \\
\text { Roorkee) }\end{array}$ & $\begin{array}{l}11.7 \pm \\
4.0\end{array}$ & $3.2 \pm 3.1$ & $\begin{array}{l}70.6 \pm \\
10.5\end{array}$ & $\begin{array}{l}14.6 \pm \\
12.4\end{array}$ & Present study \\
\hline
\end{tabular}

*Municipal wastewater (Primary effluent of domestic and industrial origin)

\section{2. $C O D, B O D_{5}$, and TSS removal}

The full-scale SBR plant designed for 3.2 MLD flow (average flow of 3 MLD and Recycle discharge of 0.2 MLD) was operated under HRT of 18.1 hours for $\mathrm{BOD}_{5}, \mathrm{COD}$, and TSS removal during the study period. The plant achieved the targeted design quality of treated sewage for BOD and TSS $\leq 10 \mathrm{mg} / \mathrm{L}$, and COD $\leq 50 \mathrm{mg} / \mathrm{L}$. There was no chemical addition except chlorine (bleaching powder) for disinfection. The plant has shown excellent results since commissioning and has excellent flexibility to handle significant influent load variations, and attained reasonably low values of operating parameters in the effluent (Figure S2, Supplementary Material). COD, BOD ${ }_{5}$ and TSS removal were $94.9 \pm 3.6 \%, 95.4 \pm 2.7 \%$, and $95.4 \pm 1.6 \%$ respectively in the $3-M L D$ SBR plant. 


\subsection{Nitrogen removal, the effect of $\mathrm{C} / \mathrm{N}$, and the effect of variations}

The overall nitrification of ammonia was $96.7 \pm 2.6 \%$; total nitrogen removal was $69.1 \pm 11.5 \%$. Figure S3 (Supplementary Material) illustrates the total nitrogen, ammonia, and nitrates in influent and effluent. During the sampling period, the plant runs efficiently with total nitrogen in effluent achieved $\leq 10 \mathrm{mg} / \mathrm{L}$.

The average TN in the effluent was $9.7 \pm 3.0 \mathrm{mg} / \mathrm{L}$. Higher values in the effluent that crossed the Indian standards (Recent Notified Effluent standards of National Green Tribunal (NGT) (2019)) are observed at COD: TN range of 12-14 and 18-20 (Figure 3). However, at COD: TN ratios $<11$, the TN in the effluent was $<10 \mathrm{mg} / \mathrm{L}$. According to Randall (1992), entire denitrification can be attained at a TCOD/ TKN ratio of 7, which is also observed in the present study. Generally, at least a value of 9 is obligatory for accomplishing biological nutrient removal (Goronszy 1992). Isaacs and Henze (1994) proposed that 1.5 to $2.5 \mathrm{~g} \mathrm{COD} / \mathrm{g} \mathrm{P}$ is utilized for the removal of phosphates while the COD: TN ratio for denitrification varies from 3.5 to $4.5 \mathrm{~g} \mathrm{COD/g} \mathrm{N}$ (Pochana and Keller 1999), which is near to the hypothetical requirement supporting denitrification with no COD loss during aerobic processes. A characteristic variation in the $\mathrm{C} / \mathrm{N}$ ratio in the plant can be seen in Figure 3. Figure 3 represents that in the wastewater, the optimum COD: TN Ratio at which excellent TN Removal was obtained at ratios between 7 and 11. The range contained eight values of TN Removal in which best removal 83\% was observed at COD: TN of 9 .

\subsection{Relationship with rbCOD (Readily Biodegradable COD) and Simultaneous Nitrification and Denitrification undergoing in the plant}

Denitrifiers are recognized to struggle in search of carbon supply amid other heterotrophs; a lesser $\mathrm{C} / \mathrm{N}$ ratio in the incoming wastewater outcomes in a quick carbon shortage, originating unstabilized SND (Zhao et al. 2008). SND in the SBR plant was $76 \pm 9 \%$, where average ammonia from the influent wastewater was removed from $\sim 21.8 \mathrm{mg} / \mathrm{L}$ to $\sim 0.7 \mathrm{mg} / \mathrm{L}$ in the effluent. At the same time, absolute nitrate observed in the influent and effluent was $\sim 0.9 \mathrm{mg} / \mathrm{L}$ and $\sim 5.6 \mathrm{mg} / \mathrm{L}$, respectively. Detailed analysis of 3 MLD SBR, IIT Roorkee, was performed to analyze the relationship between $\mathrm{rbCOD} \%$ and SND\% (Figure 4).

\subsection{Effect of rbCOD: TN and $B O D_{5}: T K N$ on the denitrification rate and the $T N$ removal}

To carry out the denitrification process during biological treatment, the presence of readily biodegradable organic carbon is an indispensable factor (Randall 1992). Under anaerobic/ anoxic conditions, denitrification capacity is evaluated by the requirement of available carbon source of nitrates, which is managed by the readily biodegradable fraction of COD (Tas et al. 2009). Operation data from 3 MLD SBR showed the effects of the influent rbCOD: TN ratios on the effluent Nitrate concentrations operating in SND mode (Figure S4), and the relationship showed a decreasing linear trend. It can be observed that higher rbCOD specifically is needed to achieve denitrification and which strongly influences SND performance (Pochana and Keller 1999; Jimenez et al. 2010). Higher rbCOD: TN ratio above 2.0 showed higher SND (> 80\%). 
The $\mathrm{BOD}_{5}$ : TKN ratio also shows significant effects on denitrification rates and $\mathrm{TN}$ removal in the plant (Figure S4). At a higher $\mathrm{BOD}_{5}$ : TKN ratio above 6.0 , more than $80 \%$ denitrification was achieved, and when the $\mathrm{BOD}_{5}$ : TKN fraction dropped below 2, lesser denitrification was attained (Jimenez et al. 2010). Similarly, at higher values of soluble $\mathrm{BOD}_{5}$ to $\mathrm{TKN}$ ratio $\left(\mathrm{SBOD}_{5}: \mathrm{TKN}\right)>3.0$, better and consistent TN removal was observed in the plant, and effluent TN reached the stabilized results of $8.1 \pm 2.2 \mathrm{mg} / \mathrm{L}$ while lower values of $\mathrm{SBOD}_{5}$ : TKN $<1.6$ showed higher TN in effluent $11.1 \pm 3.9 \mathrm{mg} / \mathrm{L}$ (Figure S4, Supplementary Material).

\subsection{Total Nitrogen Balance}

In the SBR, a typical total nitrogen (TN) balance has been observed (figure 5). The destination of the incoming $\mathrm{TN} \sim 74.6 \mathrm{Kg} / \mathrm{d}$ in the inlet is followed by its expedition in three ways; a) some quantity of it went to the dissipated sludge: $14.2 \pm 7.2 \%(9.7 \pm 4.3 \mathrm{Kg} / \mathrm{d}) \mathrm{b})$ some part left untreated in the effluent: 33.9 $\pm 11.9 \%(23.5 \pm 7.4 \mathrm{Kg} / \mathrm{d})$, and c) the remaining (largest part) found is released as $\mathrm{N}_{2}$ gas via denitrification: $51.8 \pm 13.8 \%(41.4 \pm 24.1 \mathrm{Kg} / \mathrm{d}$ ) (Dold et al. 1995, Srivastava and Kazmi 2020). According to primary treated water, the removal of nitrogen by incorporation in domestic wastewater treatment varies from $8-20 \%$, and noticeable outcomes observed in the present study attributed to $~ 14 \%$ removal by assimilation (Srivastava and Kazmi 2020). The quality of the sludge after biological treatment was excellent and showed high-quality settling features at $\mathrm{SVI}<50 \mathrm{~mL} / \mathrm{g}$ and $\mathrm{SV}_{30}$ of $250-350 \mathrm{~mL} / \mathrm{L}$.

\subsection{Phosphorus removal, the effect of $C / P$, and the impact of variations}

TP and $\mathrm{PO}_{4}-\mathrm{P}$ in influent was $6.1 \pm 2.4 \mathrm{mg} / \mathrm{L}$ and $2.7 \pm 1.0 \mathrm{mg} / \mathrm{L}$ and in effluent was $3.6 \pm 1.8 \mathrm{mg} / \mathrm{L}$ (removal $42.0 \pm 15.3 \%$ ) and $1.8 \pm 0.7 \mathrm{mg} / \mathrm{L}$ (removal $31.3 \pm 24.9 \%$ ) respectively (Figure S5, Supplementary Material). In enhanced biological phosphorus removal systems, polyphosphate Accumulating Organisms (PAOs) uptake organic substrate, PHB formation occurs by sequestering rbCOD- by PAOs, $\mathrm{PO}_{4}-\mathrm{P}$ is released, and exogenous $\mathrm{BOD}$ is consumed in anaerobic condition. PAOs take up volatile fatty acids (VFA) in anaerobic zone/ condition, and VFAs got converted into Polyhydroxyalkanoates (PHA) through hydrolysis of glycogen, which is the only means of energy for PAOs, intended for this mechanism (Mino et al. 1998). At the same time, PHB degradation occurs in the aerobic zone; PAOs uptake phosphate and form polyphosphates in cells during the oxic condition. Therefore carbon to phosphorus ratio in the wastewater is an important parameter regarding biological phosphorus removal in the treatment plants. Readily Biodegradable COD (rbCOD) concentration in the influent predicts the biological phosphorus removal process's performance more accurately consists of complex soluble COD that can be fermented to VFA (Broughton et al. 2008). The variations in different $\mathrm{C} / \mathrm{P}$ ratios and effluent TP and PO4-P in the effluent are shown in figure 6.

3.8. Relationship with Readily Biodegradable COD and Biological Phosphorus Removal undergoing in the plant 
The fraction of rbCOD to TP is an improved implication of the biological phosphorus removal process performance besides the total COD: TP ratio suggested in classic models. In the EBPR process, the soluble readily biodegradable fraction of COD gets fermented to VFA in the anaerobic zone (Majed and Gu 2019). The examined stoichiometry requisite of carbon for an elemental quantity of phosphorus to be removed has subsisted in the range of 10 to $20 \mathrm{mg}$ rbCOD/ mg P eliminated (Barnard et al. 2017). Elevated rbCOD/P ratios, i.e., 40 to $50 \mathrm{mg} \mathrm{rbCOD} / \mathrm{mg}$ P, have been perceived to be related to GAOcontrolled diversity, and smaller ratios $<10$ to $20 \mathrm{mg}-\mathrm{rbCOD} / \mathrm{mg} P$ have been related with PAO ledcommunity (Broughton et al. 2008). In 3 MLD SBR plant $\mathrm{mg}$ rbCOD/ $\mathrm{mg}$ TP ratio was on an average $9.6 \pm$ 4.8 and $\mathrm{mg} \mathrm{COD} / \mathrm{mg} \mathrm{TP}$ and $\mathrm{mg} \mathrm{BOD}_{5} / \mathrm{mg}$ TP ratio were observed as $81.8 \pm 37.2$ (should be $>45$ ) and $33.3 \pm 14.5$ (should be $>20$ ) respectively. Because of the rbCOD/TP ratio's unfulfilled requirement of 10 to 20 , TP Removal was $42.0 \pm 15.3 \%$, and EBPR was only $17.8 \pm 17.3 \%$. Enhanced uptake is being ascertained after excluding the $1 / 100^{\text {th }}$ part of $\mathrm{mg} \mathrm{BOD/L}$ from Total Phosphorus removed, i.e., exceeded from $\mathrm{PO}_{4}-\mathrm{P}$ uptake by $\sim 2.67 \%$ of cell biomass. Figure 7 exhibits the effect of rbCOD/TCOD (\%) and $\mathrm{rbCOD} / \mathrm{sCOD}(\%)$ on the total phosphorus and orthophosphate removal of the plant.

Zone-wise, $\mathrm{PO}_{4}-\mathrm{P}$ removal is illustrated in figure S6 (Supplementary Material). The release of phosphate is observed as $26.4 \%$ in the anoxic selectors, and then a reduction in the aeration tanks was observed as $52.9 \%$, which shows uptake of $26.5 \%$. Return Activated Sludge (RAS) in nitrifying processes planned to eliminate ammonia includes considerable nitrate concentrations that are not suited to two-stage (anoxicaerobic) EBPR systems. In the following circumstances, prerequisites must be taken care of for denitrifying the return solids to circumvent negotiating the anaerobic zone's integrity, which might be fulfilled by having one or more anoxic phases (Minnesota Pollution Control Agency 2006). Other than the requirements of rbCOD: TP ratio, the necessary conditions of EBPR are VFA to TP ratio should be more than 7, and pH supposed to be between 8.0 to 8.5 and 7.0 to 7.5, for anaerobic and aerobic zones respectively, for efficient EBPR process (Mino et al. 1998). ORP in the anaerobic, anoxic, and aerobic zones should cover the range of $-100 \mathrm{mV}$ to $-200 \mathrm{mV},-50 \mathrm{mV}$ to $+50 \mathrm{mV}$, and +100 to $+300 \mathrm{mV}$, respectively (Burkhardt 2012). Acid formation from the fermentation of rbCOD occurs at an ORP of -100 to $-250 \mathrm{mV}$ (Goronszy et al. 1992, 1996). Even the sludge's phosphorous content should be reasonably more significant than the stoichiometric value. The phosphorous content in the sludge was $1.95 \pm 0.80 \%$ of MLSS in the plant.

In the anaerobic zone, VFAs are stored inside the bacterial cell. PAOs use PHAs \& PHBs in the aerobic process during a lack of exogenous substrates sequestering soluble phosphorus as poly-phosphates (known as $\mathrm{P}$ uptake). This uptake is greater than the $\mathrm{P}$ released in anaerobic processes since substantial additional energy is generated by aerobic oxidation of the accumulated carbon compounds than used to conserve them in an anaerobic environment (Oehmen et al. 2007). Anaerobic long-covered sewer lines contain a high amount of VFAs and compensate for the need for a complete anaerobic chamber before SBR basins. Wastewaters that are more septic, from collection systems in warm climates and minimal slope, will contain a high concentration of VFAs (Broughton et al. 2008). But, if fermentation could not happen in the collection system, it must take place in the anaerobic region so that EBPR can work sound. 
The hydraulic retention times of the anaerobic zone must fulfill the limit between 0.5 to 2.0 hours (Burkhardt 2012). However, RAS's falling in the anoxic chamber of selectors dampens plants' productivity in removing TP biologically. If the anoxic selectors could not reach the particular requirement, sufficient formation of VFAs might not occur. VFAs' sources were observed inadequate for proper conditions of PAOs' growth and effective EBPR in the 3 MLD SBR plant. Though some fermentation of rbCOD occurred at an ORP of $-90 \pm-24 \mathrm{mV}$ in the third compartment of anoxic selectors of the SBR plant, and EBPR occurred as $\sim 18 \%$.

\subsection{Storage products (PHBS) for SND and EBPR}

The prospectives for PHB to supply electrons for an efficient SND process can be observed in SBR plants. The non-rapid degradation characteristics of PHB clarifies that it is a deserving active substrate for the SND process (Third et al. 2003; Miao et al. 2015). Internally stored PHBs are removed much slowly than the soluble substrate and therefore can be employed as an electron donor for denitrification when exogenous carbon sources are not present (Table S4, Supplementary Material) (Third et al. 2003). The capacity of heterotrophs to quickly sequester the soluble substrate and conserve it as a slowly biodegradable polymer signifies expedient chances in preserving reducing power for SND. PHBs are found sufficient as granules within a filamentous sludge or inside the large flocs governing SND.

Granular formation of biomass, producing better-quality supernatant- biomass separation and high concentrations of mixed liquor suspended solids (MLSS), and its capability to achieve more excellent loading rates have been monitored in several anaerobic processes. However, the mechanism of this phenomenon remains to be incomprehensible (Morgenroth et al. 1997). As discussed earlier in the phosphorus removal; Polyphosphate Accumulating Organisms (PAOs) uptake organic substrate, and PHB formation occurs by sequestering rbCOD, $\mathrm{PO}_{4}-\mathrm{P}$ is released, and exogenous $\mathrm{BOD}$ is consumed in anaerobic condition. PHA, glycogen, and poly-P are the storage products for PAOs. PHAs are 0.2 to 0.5 $\mu \mathrm{m}$ sized granules, which are present in the cytoplasm of the cell enclosed by a film (membrane). Frequent PHA preserved by bacteria is Poly- $\beta$-hydroxybutyrate (PHB), a lipid-resembling polymer of 3hydroxybutyrate. However, there are some poly-P collecting bacteria (e.g., M. phosphovorus), which do not accumulate PHA but preserve trehalose, poly-P, and glycogen (Sathasivan 2009).

The literature suggests that PHB formation has a significant role during the processes of SND (a potential substrate for denitrification) and EBPR (a potential substrate for excess phosphorus uptake by PAOs in the aerobic phase). In the 3-MLD SBR plant, some PHBs are observed in anoxic selectors and aeration tanks' sludge samples. Qualitative microscopic observations were carried out in mixed liquor samples of aeration tanks and selectors (Figure 8). $100 \mu \mathrm{L}$ sub-samples of sludge were examined under 100X magnifications (with immersion oil) as per prescribed Protocol (USEPA, 1987).

\subsection{Microbial characteristics and identification}

This study substantiated the prospect of attaining granular sludge in an anaerobic/aerobic sequencing batch reactor with a complete SND and biological phosphorus removal performance. Operational 
litheness of the SBR (capability to lessen settling time, initial reactor volume, etc.) played a pivotal role in promoting compact granular biomass formation and maintenance. After staining the samples for PHB, microscopic observations revealed that the biomass consisted of a microbial community diverse in terms of morphology, physiology, and anaerobic PHB storage. The biomass assessment concerning the microscopic features of the EBPR phenomenon, SND, and phylogenetic identification of the microbial populations should be performed simultaneously to put adjacent to the function of microorganisms and identity observed in EBPR systems (Dulekgurgen et al. 2003).

Several protozoa species are identified in the sludge samples (Table S5, Supplementary Material). Protozoa species like arcella, vorticella, and opercularia are dominant, while filamentous are lesser in the plant's sludge. Lower SVIs, good microbiota (rich in floc-formers), and excellent effluent characteristics are interrelated. The elemental source for the natural selection of non-filamentous organisms is the management of the surrounding during the primary contact of the influent sewage, where a large amount of $\mathrm{SBOD}_{5}$ or $\mathrm{SCOD}$ is eliminated from the solution to the biomass in the midst of or devoid of limited oxidation (Albertson 2002). The critical situation depends upon the occurrence of DO and the food to microorganisms (F/M) ratio in the anoxic selector zones/ compartments. The accumulation of nitrates through return activated sludge or internal recycling from the nitrifying region (aeration tanks) can also contribute constructively in restraining the growth of filamentous organisms (Albertson 2002).

\subsection{Pathogens removal (Total Coliforms and Fecal Coliforms control)}

The disinfection of the finally treated effluent was carried out by Ultraviolet radiations and chlorine dosing together. The influent and effluent Total Coliforms were $3600000 \pm 80 \mathrm{MPN} / 100 \mathrm{~mL}$ and $5400 \pm 10$ MPN/ $100 \mathrm{~mL}$, respectively resulted in 3 log removal. Fecal coliforms also reduced to $35 \pm 9$ MPN/ 100 $\mathrm{mL}$ from $160000 \pm 13 \mathrm{MPN} / 100 \mathrm{~mL}$ ( 4 log removal). Fecal coliforms in the final effluent completely satisfied the latest NGT standards.

\subsection{The overall effect of qualitative and quantitative variations on plant performance}

The ratio of influent $\mathrm{BOD}_{5}$ to $\mathrm{COD}$ impacts nutrient removal performance. $\mathrm{BOD}_{5}$ : total $C O D$ signifies the biodegradable carbon content in wastewater (biochemical oxygen demand) from the whole organic matter (chemical oxygen demand) in wastewater, which is quite imperative for efficient nutrient removal in wastewater treatment plants. Therefore, the evaluation of wastewater propensity for biological treatment is widely revolving around $\mathrm{BOD}_{5} / \mathrm{COD}$ (Gajewska et al. 2015). An increasing linear trend was observed in $\mathrm{BOD}_{5}$ to total COD ratio, and TN and TP removal in the SBR plant has been observed in the plant (Figure S7, Supplementary material).

The temperature varied from $10 \otimes \mathrm{C}$ to $30 \otimes \mathrm{C}$ during the study. The average MLSS and MLVSS in the aeration tanks were 7189 and $3087 \mathrm{mg} / \mathrm{L}$ (Aeration tank 1) and 7518 and $3740 \mathrm{mg} / \mathrm{L}$ (Aeration tank 2). Average influent $\mathrm{NH}_{4}-\mathrm{N}$ decreased from $22 \pm 5.8 \mathrm{mg} / \mathrm{L}$ to $0.7 \pm 0.5 \mathrm{mg} / \mathrm{L}$ ( $96.7 \%$ removal), and TN removal was $69 \%$. DO concentration varied from $0 \mathrm{mg} / \mathrm{L}$ to $2.48 \mathrm{mg} / \mathrm{L}$ during aeration and $0.02-0.22$ 
$\mathrm{mg} / \mathrm{L}$ during settling/ decanting. ORP fluctuates between $-66 \mathrm{mV}$ to $-114 \mathrm{mV}$ in the anoxic selector compartments and reaches $\sim 140 \mathrm{mV}$ in the peak hours during the aeration phase in the SBR. It ultimately attained $\leq 50 \mathrm{mV}$ during the settling and decanting phases. Table $\mathrm{S} 1$ in the Supplementary material demonstrates the following parameters. The DO and ORP profiles with the COD and nutrient removal can be observed in Figure 9. Figure S8 (Supplementary Material) illustrates the profiles in the compartments of the anoxic selector. The third compartment of the selector ORP reduces to $<-90 \mathrm{mV}$, contributing to $39.7 \%$ denitrification. When RAS (15 - 30 minutes contact time) from aeration tanks goes to these selectors, the microorganisms meet a greater amount of substrate and limited DO concentration in the anoxic selector, natural selection of foremost floc-formers occurs. Large flocs produce, which strengthens the SND efficiency of the plant.

\section{Conclusion}

This study demonstrates the impact of pre-anoxic selector in the variation of wastewater and its influence on the treatment efficiency of the SBR plant. The plant was efficient in treating the simultaneous organic matter, suspended solids, nutrients, and pathogens in wastewater. An authentic relationship of rbCOD was observed with SND, and total phosphorus removal and some enhanced uptake of phosphorus were observed. ORP control, rbCOD: TP ratio, upcoming VFA from the sewer lines are the concrete parameters for providing characteristic enhanced biological phosphorus removal. SBR has multi-compartment anoxic bio-selectors that effectively make bigger flocs in sizes and encourage SND to occur delightfully in the aeration tanks. The soluble organics in the raw sewage are sequestered as intracellular compounds in the biomass utilized for SND. Biological phosphorus removal took place under managed cyclic aeration sequences in SBR in the aeration zone, informing good sludge devoid of bulking and foaming. Bioselector improved the sludge morphology, and the prevalence of protozoa indicated excellent sludge formation. Besides, some denitrification also occurred in the selectors. Stored substrates are visible using Sudan Black B staining, also confirming superior SND in the plants. Finally, disinfecting the effluent by UV and chlorination intensified the quality of discharged effluent and made it satisfactory for Indian effluent discharge standards. Further assessment of microbial ecology present in the full-scale plant's activated sludge could open novel wastewater treatment dimensions.

\section{Declarations}

\section{Acknowledgment}

The first author is thankful to the Indian Institute of Technology, Roorkee, for Ph.D. assistantship during the study and monitoring and researching the 3 MLD SBR plant, authorized by IIT Roorkee. The authors are also thankful to the operator and workers inside the plant who cooperated during regular sampling and monitoring of the plant.

\section{Declaration of interests}


\The authors declare that they have no known competing financial interests or personal relationships that could have appeared to influence the work reported in this paper.

\The authors declare the following financial interests/personal relationships, which may be considered as potential competing interests:

\section{Ethical Approval}

Not Applicable

\section{Consent to participate}

The authors have consented to participate in the study.

\section{Consent to publish}

All the authors have consented to publish the study.

\section{Authors Contribution}

All the authors have participated in:

1. Conception and design, or analysis and interpretation of the data.

2. Drafting the article or revising it critically for important intellectual content.

3. Approval of the final version.

\section{Credit Author Statement}

Ghazal Srivastava: Experiments, Data collection, Analysis, and Writing- original draft. Ankur Rajpal: Writing- Reviewing, and Editing. Anwar Khursheed: Writing- Reviewing, and Editing. Ashok Kumar Nadda: Reviewing and Editing. Vinay Tyagi: Reviewing and Editing. Absar Ahmad Kazmi: Supervision, Validation, and Resources.

\section{Funding}

The Ph.D. fellowship (MHRD) is being provided to the first author by the Indian Institute of Technology, Roorkee, during the study.

No other funds, grants were received.

\section{Competing Interests}

The authors declare no competing interest.

\section{Availability of data and materials}


For the data available with the paper and Supplementary files: The authors confirm that all the data underlying the findings are fully available without restriction.

\section{References}

1. Albertson OE (2002) Technology Assessments: Activated Sludge Bioselector Processes (Project). Water Environment Research Foundation.

2. APHA, AWWA, WPCF (2005) Standard Methods for the Examination of Water and Wastewater. $22^{\text {nd }}$ Edn. American Public Health Association, Washington, DC.

3. ATV-A. 131 (2000) The dimensioning of single-stage sewage treatment plants with activated sludge; German ATV-DVWK Rules and Standards: Hennef, German.

4. Barnard J, Dunlap P, Steichen M (2017) Rethinking the mechanisms of biological phosphorus removal. Water Environment Research 89 (11): 2043-2054. DOI: $10.2175 / 106143017 X 15051465919010$

5. Biological phosphorous removal- an operator's guide (2012) https://www.miwea.org/docs/Biological\%20Phosphorous\%20Removal\%20-\%20An\%200perator\%27s\%20Guide.pdf

6. Broughton A, Pratt S, Shilton A (2008) Enhanced biological phosphorus removal for high strength wastewater with a low rbCOD:P ratio. Bioresource Technology 99(5): 1236-41. DOI: 10.1016/j.biortech.2007.02.013

7. Burkhardt G (2012) Biological Phosphorus Removal, Operator's Guide. https://www.miwea.org/docs/Burkhardt\%20Presentation.pdf

8. Choi YY, Baek SR, Kim JI, Choi JW, Hur J, Lee TU, Park CJ, Lee B (2017) Characteristics and biodegradability of wastewater organic matter in municipal wastewater treatment plants collecting domestic wastewater and industrial discharge. Water, 9, 409. https://doi.org/10.3390/w9060409

9. Davis ML (2013) Water and wastewater engineering- design principles and practice. Tata Mc GrawHill publication Co., New Delhi.

10. Dulekgurgen E, Ovez S, Artan N, Orhon D (2003) Enhanced biological phosphate removal by granular sludge in a sequencing batch reactor. Biotechnology Letters 25: 687-693. DOI:

10.1023/a:1023495710840

11. Ekama GA, Dold PL, Marais GVR (1986) Procedures for determining influent COD. Fractions and the maximum specific growth rate of heterotrophs in activated sludge systems. Water Sci. Technol., 18: 94-114.

12. Gajewska M, Jóźwiakowski K, Ghrabi A, Masi F (2015) Impact of influent wastewater quality on nitrogen removal rates in multistage treatment wetlands. Environ Sci Pollut Res, 22: 12840-12848. DOI: $10.1007 / \mathrm{s} 11356-014-3647-4$

13. Goronszy MC (1992) In Course Notes on "Intermittently operated activated sludge plants." Department of Chemical engineering, University of Queensland, Australia. 
14. Goronszy MC, Demoulin G, Newland M (1996) Aerated denitrification in full-scale activated sludge facilities. Water Sci. Technol. 34 (1-2): 487-491. https://doi.org/10.1016/0273-1223(96)00546-X

15. Henze M, Harremoes P, Jes la Cour Jansen AE (2002) Oczyszczanie.Scieków. Procesy Biologiczne i Chemiczne. Wydawnictwo Politechniki Swi ، etokrzyskiej w Kielcach: Kielce, Poland.

16. Isaacs SH, Henze M (1994) Controlled carbon source addition to an alternating nitrificationdenitrification wastewater treatment process including biological P removal. Wat Res. 29: 77-89. https://doi.org/10.1016/0043-1354(94)E0119-Q

17. Jimenez J, Dursun D, Dold P, Bratby J, Keller J, Parker D (2010) Simultaneous NitrificationDenitrification to Meet Low Effluent Nitrogen Limits: Modeling, Performance and Reliability. WEFTEC Water Environment Federation. DOI: 10.2175/193864710798158968

18. Kappeler J, Gujer W (1992) Estimation of kinetic parameters of heterotrophic biomass under aerobic conditions and characterization of wastewater for activated sludge modelling. Water Sci. Technol., 25: 125-139. https://doi.org/10.2166/wst.1992.0118

19. Khursheed A, Gaur RZ, Sharma MK, Tyagi VK, Khan AA, Kazmi AA (2018) Dependence of enhanced biological nitrogen removal on carbon to nitrogen and rbCOD to sbCOD ratios during sewage treatment in sequencing batch reactor. Journal of Cleaner Production, 171: 1244-1254. https://doi.org/10.1016/j.jclepro.2017.10.055

20. Majed N, Gu AZ (2019) Impact of Influent Carbon to Phosphorus Ratio on Performance and Phenotypic Dynamics in Enhanced Biological Phosphorus Removal (EBPR) System - Insights into Carbon Distribution, Intracellular Polymer. DOI: https://doi.org/10.1101/671081.

21. Metcalf and Eddy (2003) Wastewater Engineering Treatment, Disposal, and Reuse. Tata Mc GrawHill publication Co., New Delhi

22. Miao L, Wang S, Zhu R, Cao T, Peng Y (2015) The effect of oxygen supply on nitrogen removal via nitrite using stored substrate (PHB) as the electron donor in SBRs. Biochemical Engineering Journal, 103: 130-137 https://doi.org/10.1016/j.bej.2015.06.005

23. Mielczarek A T (2012) Microbial Communities in Danish Wastewater Treatment Plants with Nutrient Removal. Aalborg: Sektion for Bioteknologi, Institut for Kemi ogBioteknologi, Aalborg Universitet. https://vbn.aau.dk/ws/portalfiles/portal/316474228/PhD_thesis_ArturTM.pdf

24. Mino TM, Van Loosdrecht MCM., Heijnen J J (1998) Microbiology and biochemistry of the enhanced biological phosphate removal process Wat. Res 32 (11): 3193-3207

25. Oehmen A, Lemos PC, Carvalho G, Yuan Z, Keller J, Blackall LL, Reis MAM (2007) Advances in enhanced biological phosphorus removal: From micro to macro scale. Water Res. 41(11): 2271-2300 https://doi.org/10.1016/j.watres.2007.02.030

26. Ong YH, Chua ASM, Fukushima T, Ngoh GG, Shoji T, Michinaka A (2014) High-temperature EBPR process: The performance, analysis of PAOs and GAOs and the fine-scale population study of Candidatus "Accumulibacterphosphatis." Water Research. 102-112. DOI: 10.1016/j.watres.2014.06.038. 
27. Phanwilai S, Noophan P, Li C, Choo K (2020) Effect of COD: N ratio on biological nitrogen removal using full-scale step-feed in municipal wastewater treatment plants. Sustainable Environment Research, 30(24): 1-9.

28. Phosphorus Treatment and Removal Technologies (2006) Minnesota Pollution Control Agency. https://www.pca.state.mn.us/sites/default/files/wq-wwtp9-02.pdf

29. Płuciennik-Koropczuk E, Myszograj S (2019) New Approach in COD Fractionation Methods. Water, 11, 1484. DOI:10.3390/w11071484.

30. Płuciennik-Koropczuk E, Jakubaszek A, Myszograj S,Uszakiewicz S (2017) COD fractions in mechanical-biological wastewater treatment plant. Civil Environ. Eng. Rep., 24: 207-217. https://doi.org/10.1515/ceer-2017-0015

31. Pochana K, Keller J (1999) Study of factors affecting simultaneous nitrification and denitrification.Wat. Sci. Tech., 39(6): 61-68. https://doi.org/10.1016/S0273-1223(99)00123-7

32. Randall CW, Barnard JL, and Stensel HD (1992) Design and Retrofit of Wastewater Treatment Plants for Biological Nutrient Removal. Volume 5, Water Quality Management Library

33. Recent Notified Effluent standards of National Green Tribunal (NGT) 2019.

34. Rossle WH, Pretorius WA (2001) A review of characterisation requirements for in-line prefermenters Paper 1: Wastewater characterisation. Water SA Vol. 27 No. 3: 405-412. DOI: 10.4314/wsa.v27i3.4986

35. Sathasivan A (2009) Biological Phosphorus removal processes for wastewater treatment. Water and wastewater treatment technologies. https://www.eolss.net/Sample-Chapters/C07/E6-144-10.pdf

36. Sharma M, Dhingra H K (2015) Isolation and Culture Conditions Optimization For PHB Production by Pseudochrobactrumasaccharolyticum. International Journal of Science and Research (IJSR) ISSN (Online): 2319-7064, 4(10):1895-1901

37. Sozen S, Çokgör EU, Ohron D, Henze M (1998) Respirometric analysis of activated sludge behaviorII. Heterotrophic growth under aerobic and anoxic conditions. Water Res., 32: 476-488. DOI: 10.1016/S0043-1354(97)00210-8

38. Srivastava G, Kazmi A A (2020) A Study on Total Nitrogen Balance and Alkalinity Balance in a PVA Gel-Based Bioreactor. Recent Developments in Waste Management, LNCE, volume 57:205-217 (Springer Singapore). DOI: 10.1007/978-981-15-0990-2_15

39. Tas DO, Karahan O, Insel G, Ovez S, Orhon D, Spanjers H (2009) Biodegradability and Denitrification Potential of Settleable Chemical Oxygen Demand in Domestic Wastewater. Water Environment Research. DOI: $10.2175 / 106143009 \times 425942$

40. Third KA, Burnett N, Cord-Ruwisch R (2003) Simultaneous Nitrification and Denitrification Using Stored Substrate (PHB) as the Electron Donor in an SBR. Wiley Periodicals, Inc., Biotechnology and bioengineering, 83(6):706-720. DOI: $10.1002 /$ bit.10708

41. Toerien D F, Gerber A, Lötter LH, Cloete TE (1990) Enhanced Biological Phosphorus Removal in Activated Sludge Systems. Advances in Microbial Ecology, volume 11: 173-230. DOI: https://doi.org/10.1007/978-1-4684-7612-5_5 
42. USEPA (1987) Summary Report- The causes and control of Activated Sludge bulking and foaming.

43. Wentzel M C, Mbewe A, Lakay M T, Ekama G A (2000) Evaluation of a modified flocculation filtration method to determine wastewater readily biodegradable COD. WISA, Biennial Conference, Sun City, South Africa. http://citeseerx.ist.psu.edu/viewdoc/summary?doi=10.1.1.517.5571

44. Zhao CH, Peng YZ, Wang SY, Tang XG (2008) Influence of wastewater composition on biological nutrient removal in UniFed SBR process. Water Sci. Technol. 58 (4):803-810. DOI:

$10.2166 /$ wst.2008.392

\section{Figures}

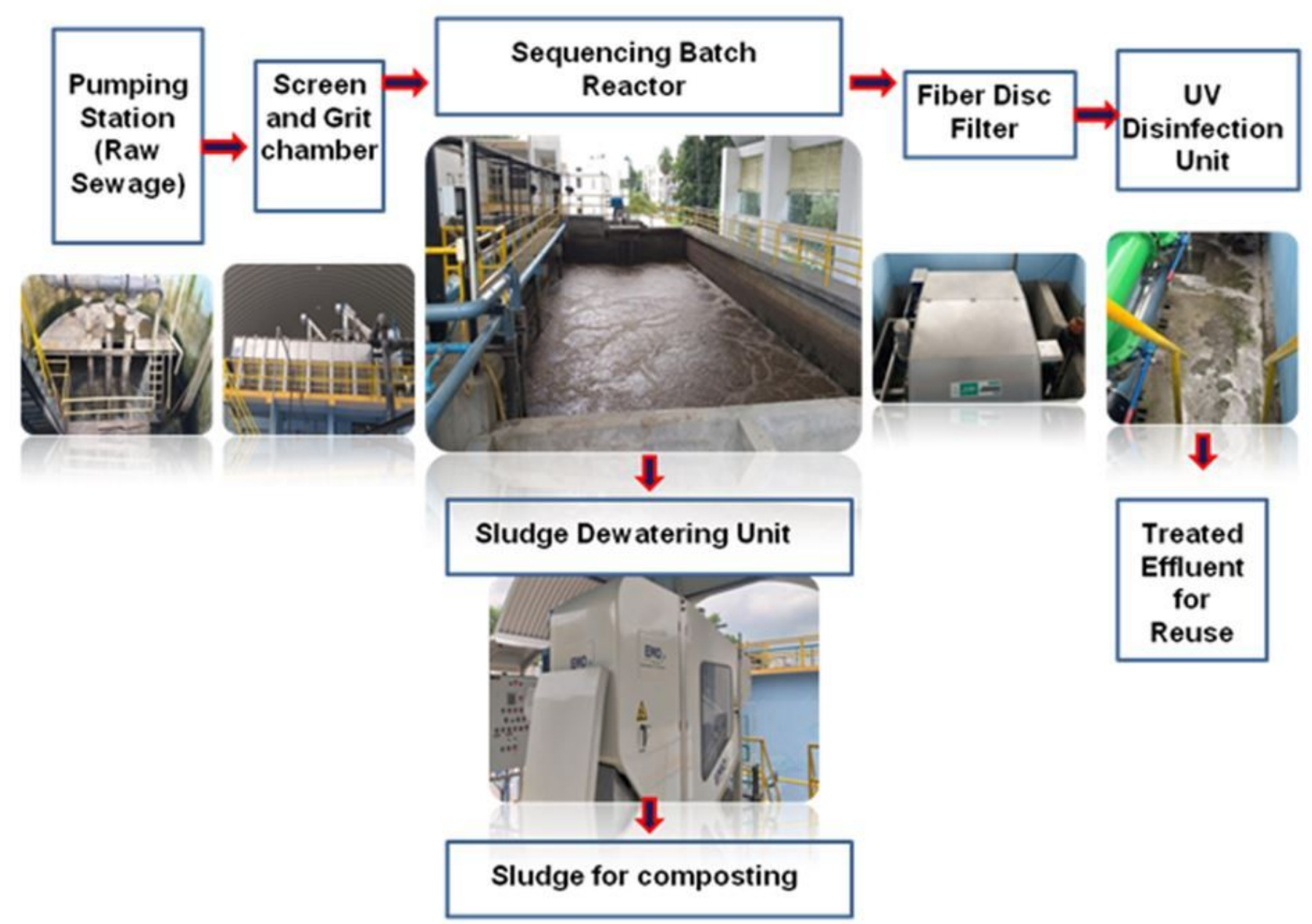

Figure 1

The layout of the full-scale 3 MLD SBR STP comprises all units. 


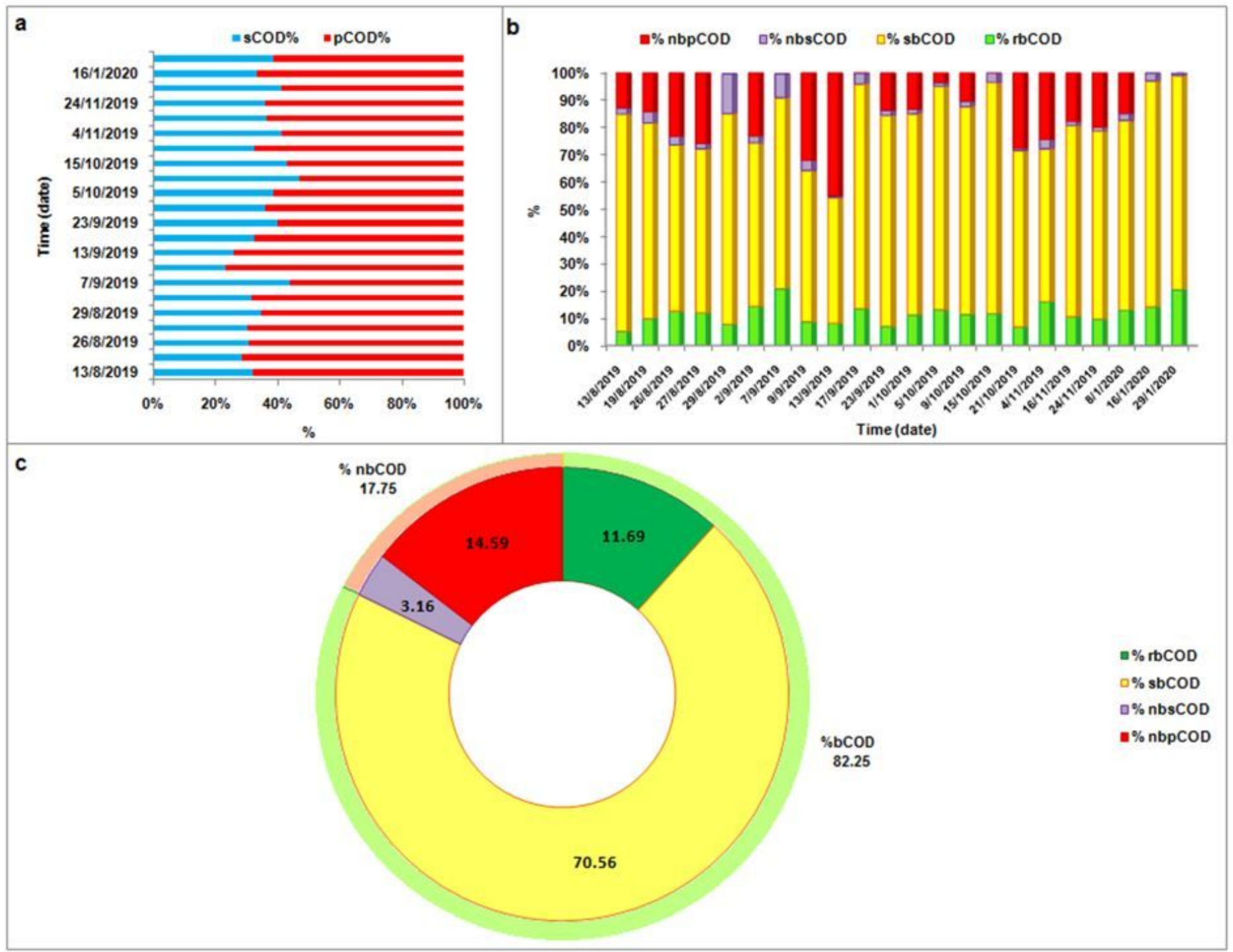

Figure 2

Wastewater characterization of 3 MLD SBR- a) soluble and particulate fractions of COD, b) bars showing different COD fractions analyzed in the SBR plant, and c) pie chart showing the average contribution of all the fractions in total COD. 


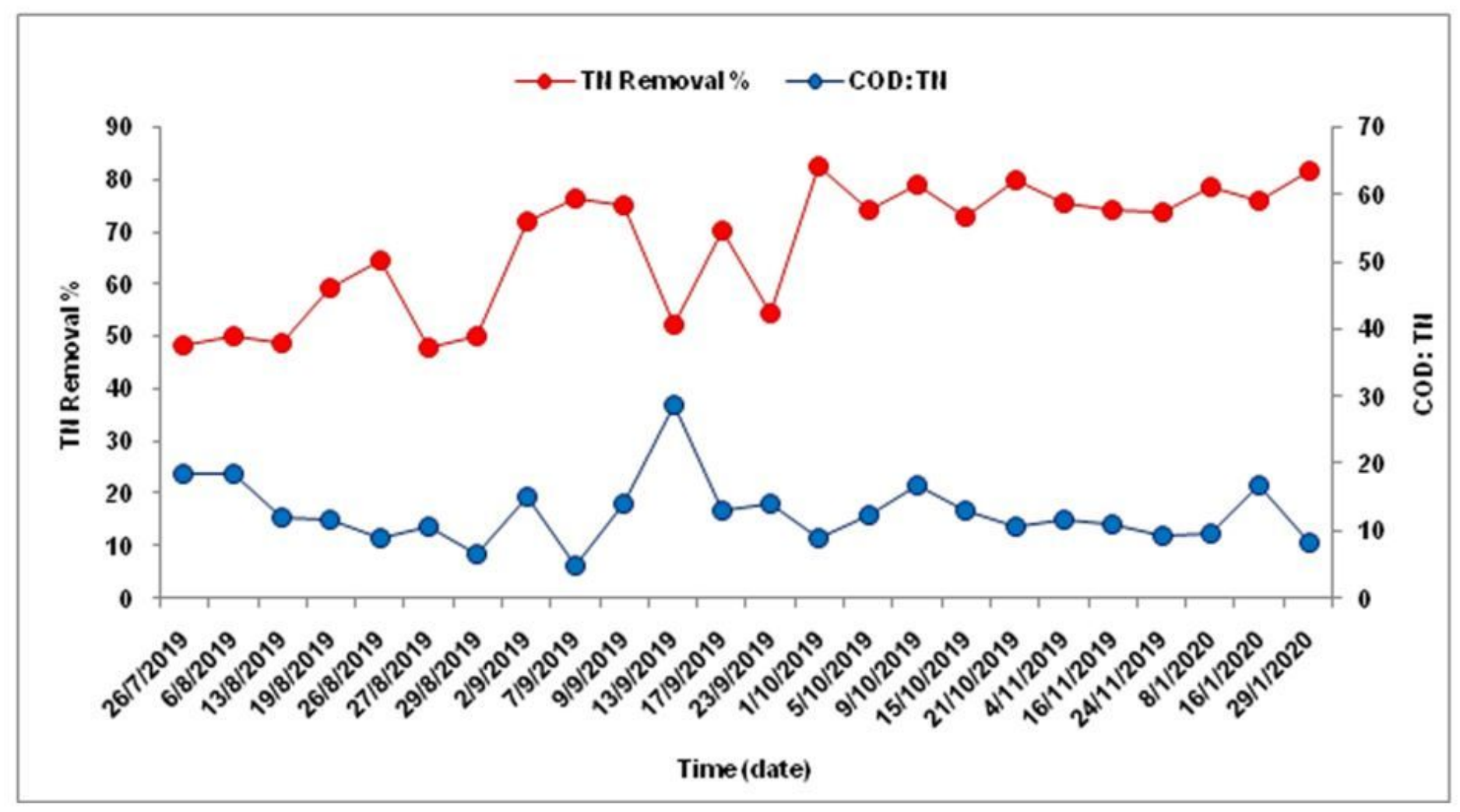

Figure 3

Variation in TN Removal \% and COD: TN ratio during the study period.

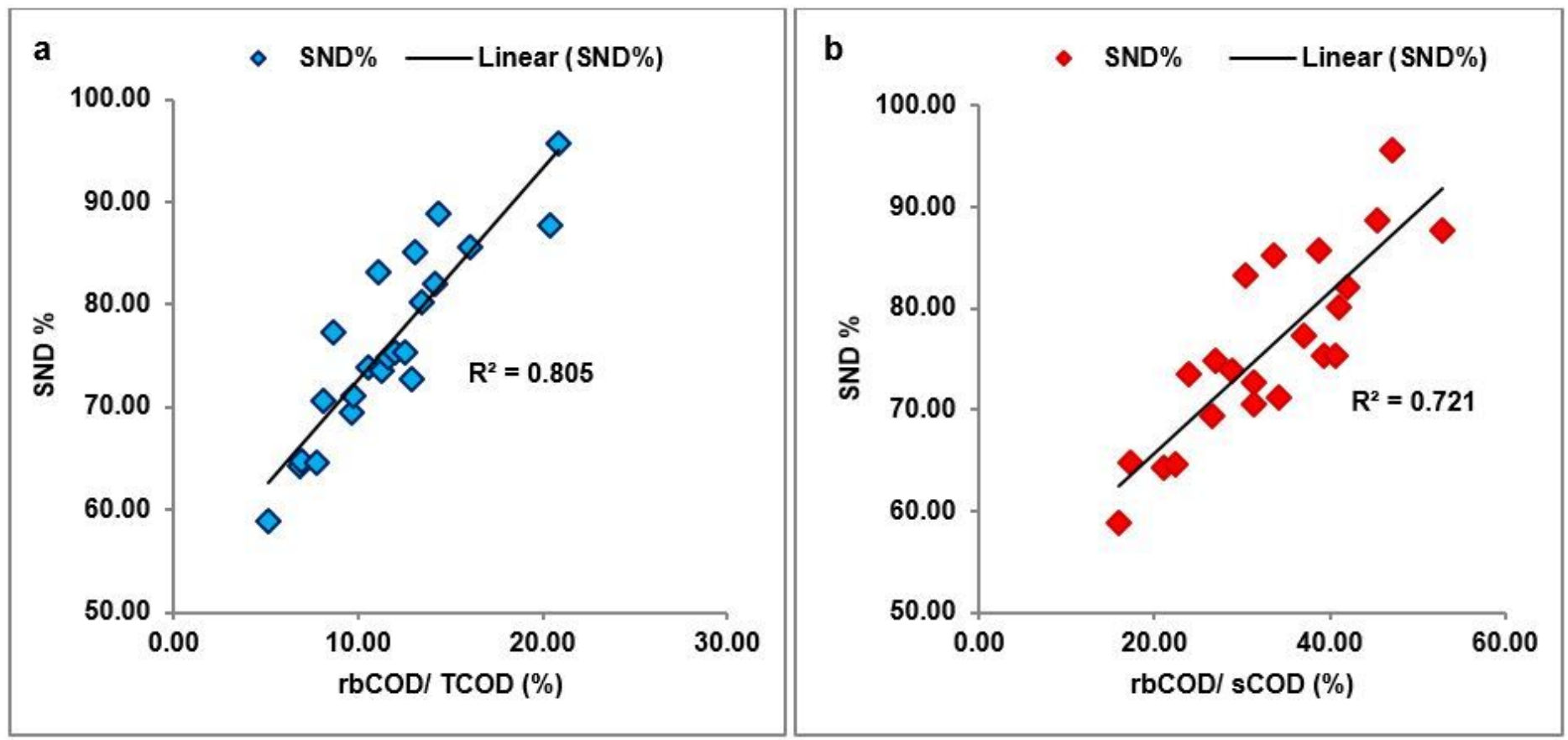

Figure 4 
Relationships between (a) SND\% with rbCOD/ TCOD (\%), and (b) SND\% with rbCOD/sCOD (\%) in 3 MLD SBR plant.

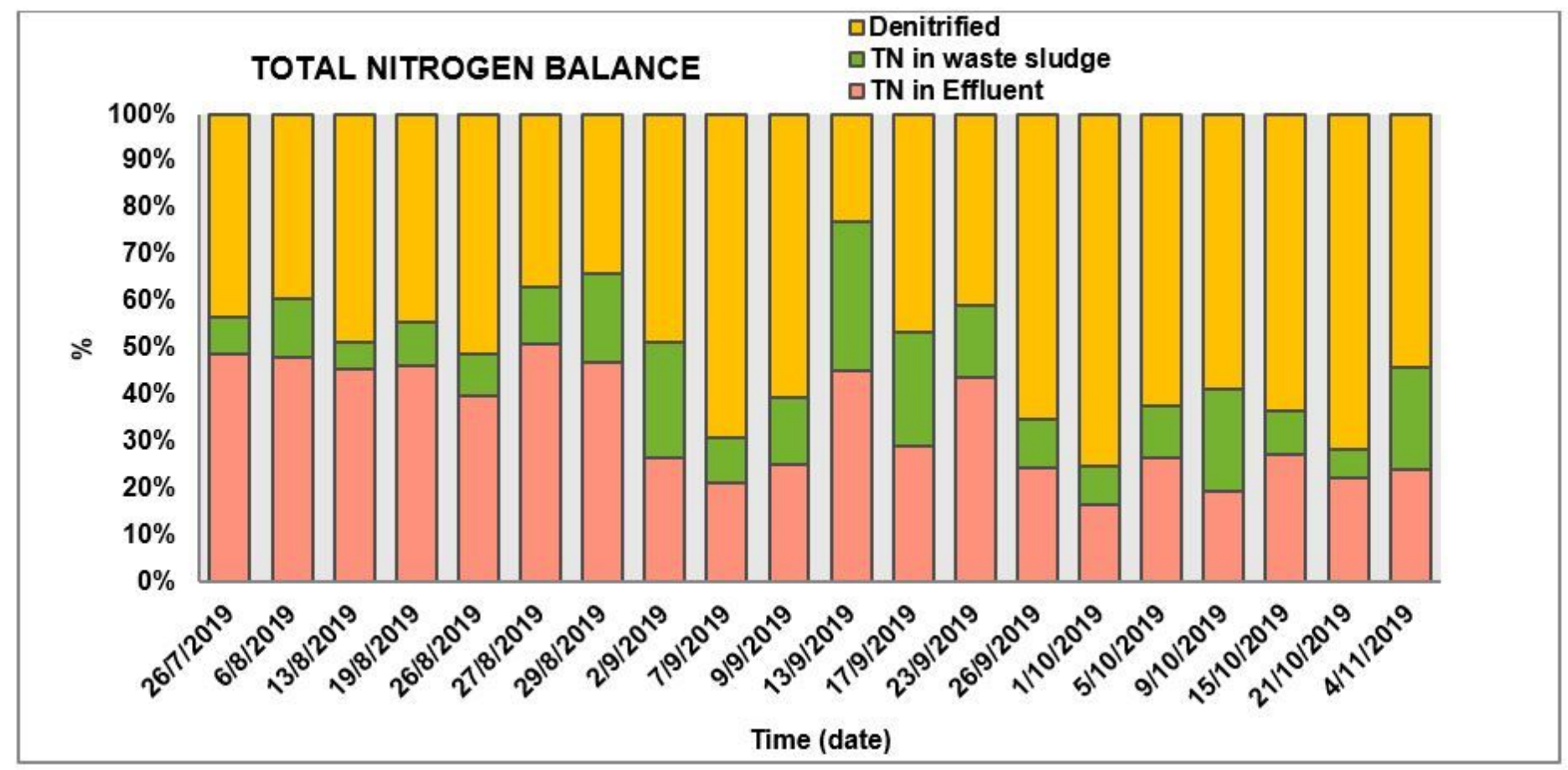

Figure 5

Total Nitrogen balance in the 3 MLD SBR plant

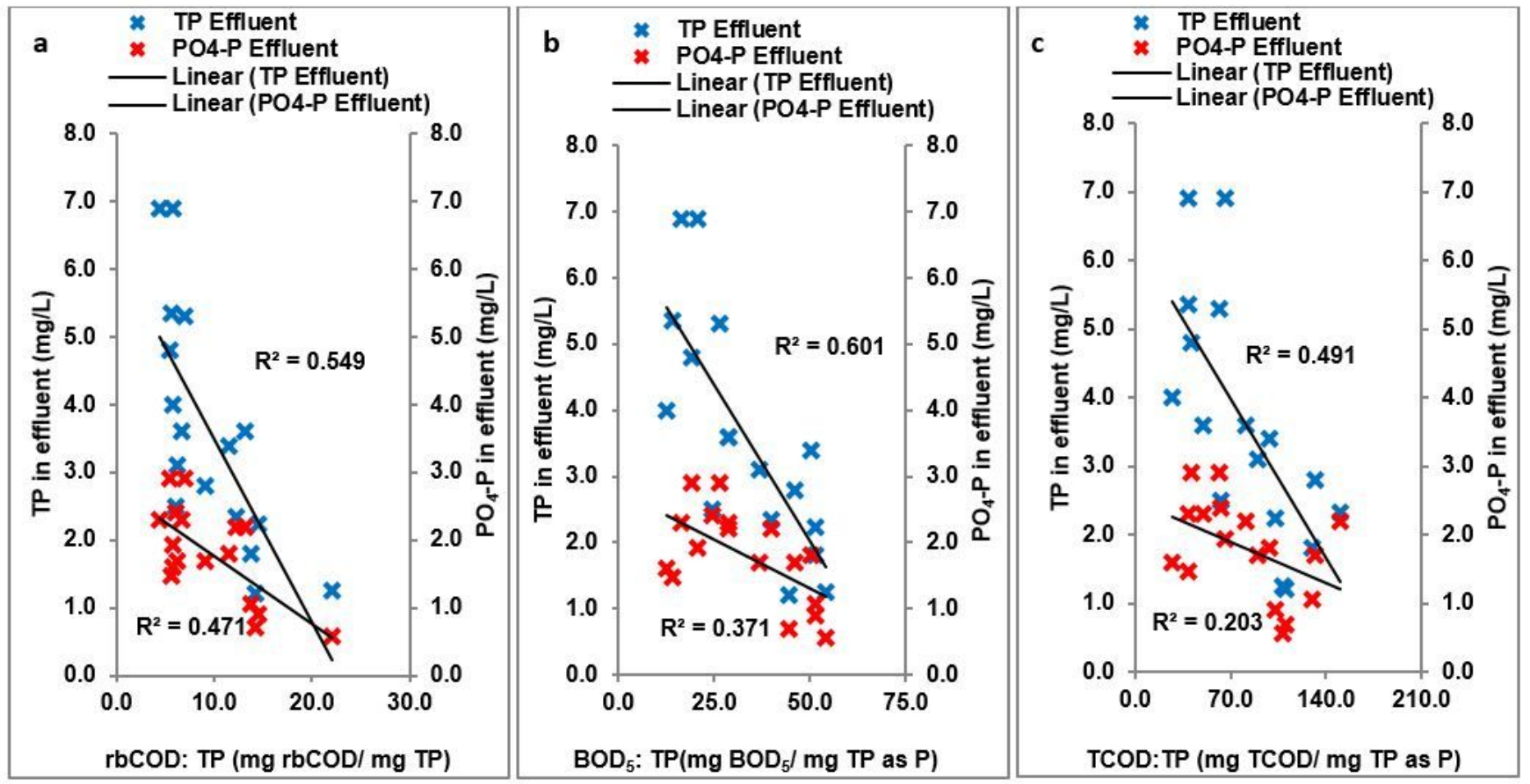

Figure 6 
Relationship between (a) rbCOD: TP, (b) BOD5: TP, (c) TCOD: TP and effluent TP and effluent PO4-P in 3 MLD SBR plant.

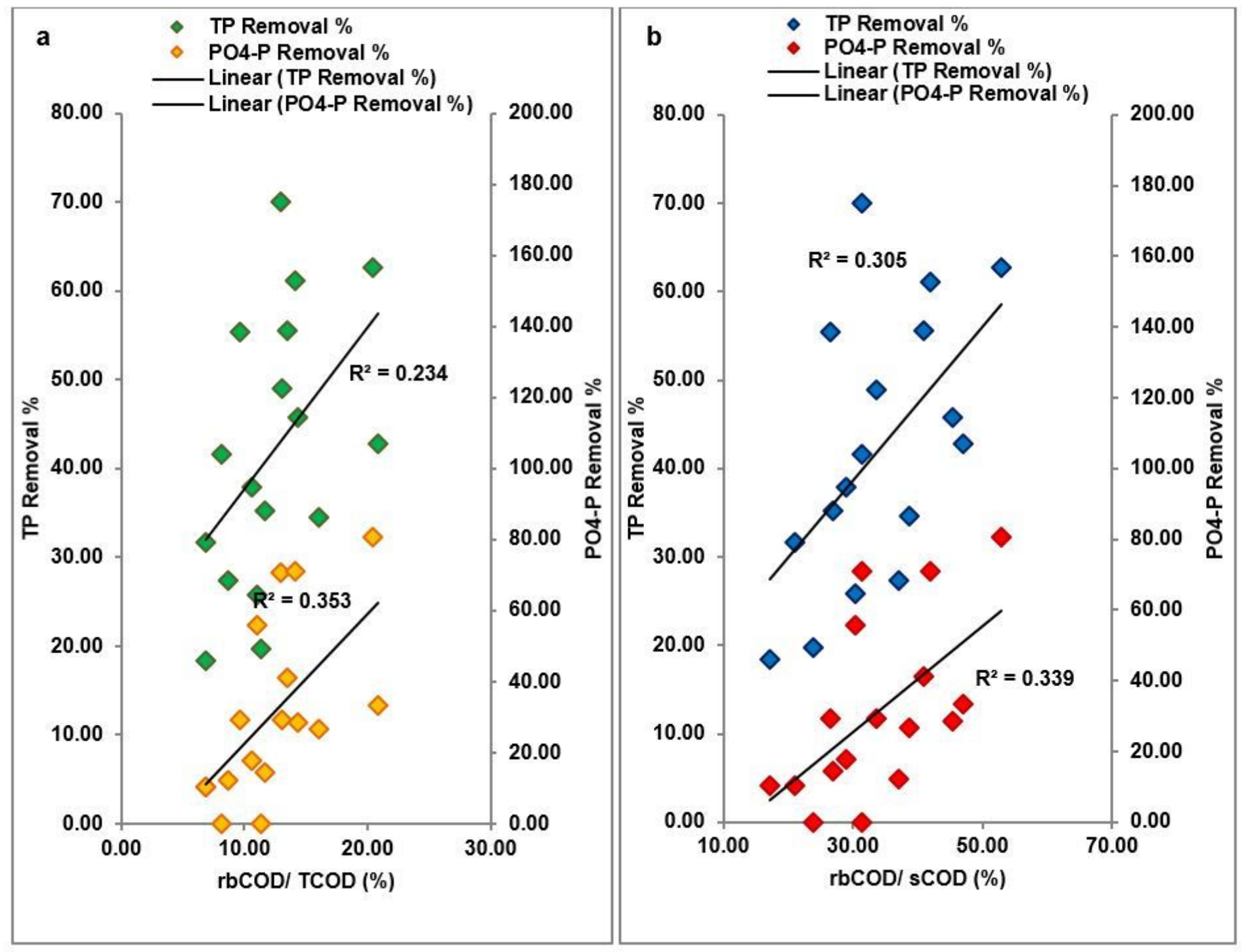

Figure 7

Relationship between (a) TP, PO4-P removal with rbCOD/TCOD (\%) and (b) TP, PO4-P removal with $\mathrm{rbCOD} / \mathrm{sCOD}(\%)$ 


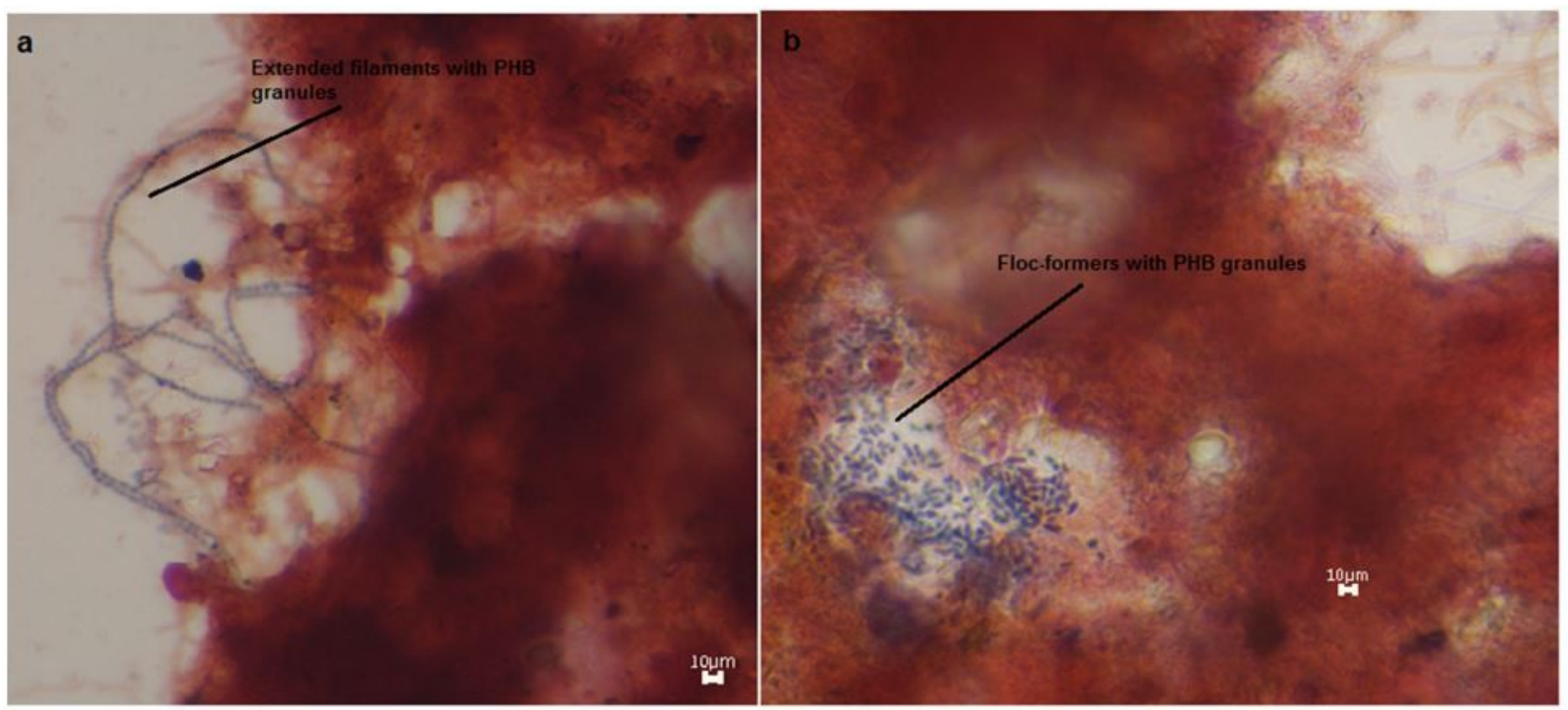

\section{Figure 8}

Bright-field micrographs of the biomass samples. Panel a) (week 26) and panel b) (week 28): all with 100X magnification (using immersion oil). Samples are collected from the aeration tanks and anoxic selector compartments treated with Sudan Black B to stain PHB- inclusions in the flocs and extended filaments [Blue-black cells: PHB (+) pink cells PHB (-)]. 


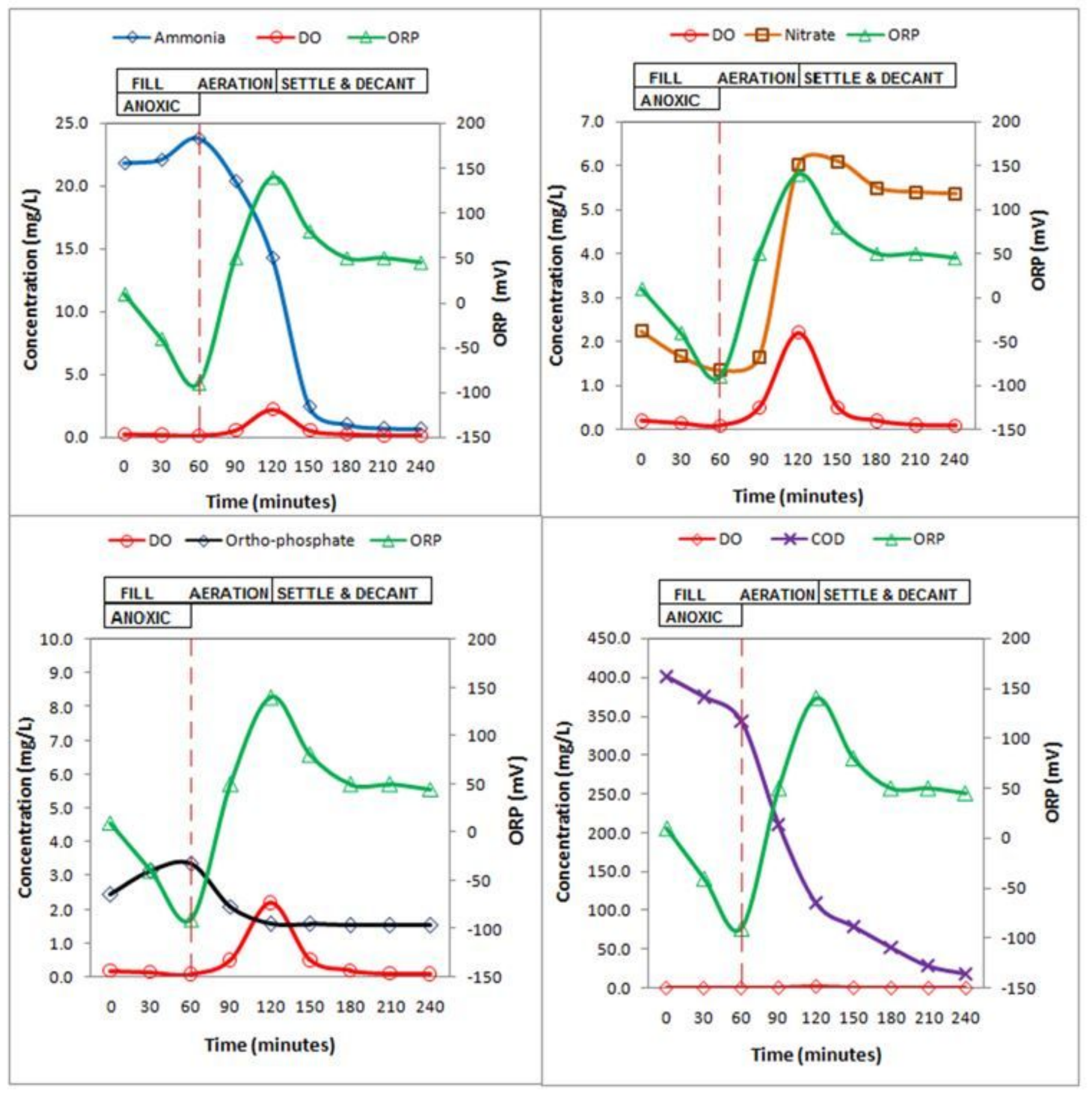

Figure 9

Cycle wise profiles of DO, ORP, Nitrate, Ammonia oxidation, COD, and orthophosphate removal

\section{Supplementary Files}

This is a list of supplementary files associated with this preprint. Click to download. 
- GA.jpg

- SupplementaryData12012021.docx 